Etnográfica

Revista do Centro em Rede de Investigação em

Antropologia

vol. 22 (1) | 2018

Vol. 22 (1)

\title{
Fados do fado: enredos, cronotopos e trânsitos culturais
}

The fates of fado: plots, chronotopes and cultural transits

\section{José Machado Pais}

\section{(2) OpenEdition}

Journals

\section{Edição electrónica}

URL: https://journals.openedition.org/etnografica/5210

DOI: 10.4000/etnografica.5210

ISSN: 2182-2891

\section{Editora}

Centro em Rede de Investigação em Antropologia

\section{Edição impressa}

Data de publição: 1 fevereiro 2018

Paginação: 219-235

ISSN: 0873-6561

\section{Refêrencia eletrónica}

José Machado Pais, «Fados do fado: enredos, cronotopos e trânsitos culturais», Etnográfica [Online], vol. 22 (1) | 2018, posto online no dia 17 maio 2018, consultado o 21 janeiro 2022. URL: http:// journals.openedition.org/etnografica/5210 ; DOI: https://doi.org/10.4000/etnografica.5210

\section{(c) (i) (8)}

Etnográfica is licensed under a Creative Commons Attribution-NonCommercial 4.0 International License. 


\section{Fados do fado: enredos, cronotopos e trânsitos culturais}

\section{José Machado Pais}

Quando viajei até Quissamã (Brasil), para conhecer um fado vindo do tempo dos escravos, fiquei intrigado com o que descobri. Por um lado, entre os fadistas circula a crença de que o fado é de Deus, vá-se lá saber porquê. Por outro lado, o fado de Deus é dançado e sapateado, em jeito afandangado, quando é sabido que o fandango batido foi das danças mais perseguidas no Brasil colonial pela sua má reputação. Na tentativa de decifração destes enigmas exploro trânsitos do fado e do fandango num enredo de disseminações, transformações, variantes e recomposições. O que descobri foi que os nós desse enredo se atam e desatam nos cronotopos desses trânsitos.

PALAVRAS-CHAVE: crenças, cronotopos, fado, fado de Quissamã, fandango, trânsitos culturais.

The fates of fado: plots, chronotopes and cultural transits - A kind of fado from slavery times took me to Quissamã, in Brazil, and I was intrigued by what I would find out. In the first place, for whatever reason, fado singers share the belief that fado belongs to God. Secondly, this God's fado is performed with dancing and stepping, reminding fandango moves, even though it is well known that the stepped fandango was one of the most persecuted dances in colonial Brazil for its bad reputation. Attempting to decode these enigmatic features, I explore transits of fado and fandango in a plot involving stances of dissemination, transformation, variation and re-composition, concluding that the knots in this plot are tied and untied in the chronotopes of such transits.

KEYWORDS: beliefs, chronotopes, fado, Quissamã's fado, fandango, cultural transits.

PAIS, José Machado (machado.pais@ics.ul.pt) - Instituto de Ciências Sociais da Universidade de Lisboa (ICS-UL), Portugal. 


\section{ALGUNS MESES DEPOIS DE TER RECEBIDO O HONROSO CONVITE PARA A} palestra na Aula Ernesto Veiga de Oliveira de 2017, Miguel Vale de Almeida enviou-me uma mensagem perguntando se já lhe poderia adiantar o título da palestra. ${ }^{1}$ No dia seguinte seguiu a resposta, agora recuperada da caixa do meu correio eletrónico: “[...] Em boa hora veio o apelo pois andava indeciso sobre o tema. Esta noite dormi sobre o travesseiro do dilema e madruguei com uma decisão". E assim surgiu, da noite para o dia como sói dizer-se, o tema sobre o qual agora discorro. Não sei se nessa noite sonhei com Gabriel Tarde, mas, ao propor-me falar dos fados do fado, tenho uma ideia de partida que a Gabriel Tarde (2007) é devida e que ele sintetizava, em seus estudos de monadologia, em apenas três palavras: existir é diferir (no sentido de divergir). Isso mesmo acontece com o fado, categoria conceptual que, na sua singularidade, não espelha a pluralidade de fados que nela se acolhem. Aliás, numa das primeiras referências ao fado no Brasil, do geógrafo e naturalista Louis Freycinet, em seu livro Voyage autour du monde, entre 1817 e 1820, a expressão que efetivamente é utilizada é fados e não fado, no singular. A referência surge quando Freycinet alude às danças lascivas do Brasil, assemelhando-as às africanas, de entre as quais destaca o lundum - a mais "indecente" -, o caranguejo e os fados, assim mesmo, no plural designados (Freycinet 1827: 21 1-212). Segundo Freycinet, todas estas danças voluptuosas eram entrecortadas com cantos soltos, tendo uma presença mais forte nos meios rurais. Os fados que viu eram dançados por quatro, seis, oito ou dezasseis pessoas.

É certo que, quando os nossos colegas e amigos estrangeiros nos perguntam sobre as origens do fado, lançam-nos uma casca de banana que nos ameaça derrapar para a busca de uma improvável identidade primordial do fado em sua pretensa unicidade e essência. Obviamente que não lhes falo de origens, mas não me furto a dar-lhes pistas sobre possíveis influências trovadorescas, árabes, africanas e ciganas. No entanto, mesmo quando thes descortino diferentes tipos de fado - o fado corrido, o fado à capela, o fado menor, o fado castiço e muitos mais (Nery 2004) -, eles insistem em querer saber a origem dessa variedade. O que então lhes digo é que, na origem, o que temos são conceções míticas do fado que correspondem a construções ou invenções de uma tradição (Hobsbawm 2000 [1983]). Nesse registo mitológico invocam-se as moiras helénicas no espírito do fado (Barreto 1923: 8); assevera-se que já Estrabão, admirável geógrafo grego do tempo de Cristo, se impressionara com o fado batido dos lusitanos; ou recordam-se as "dez mil guitarras" encontradas, em 1578, nos despojos da batalha de Alcácer-Quibir (Carvarel, Ambassade en Espagne et en Portugal, 1852?, apud Braga 1885: 407-408; Barreto 1923: 28;

1 Este texto foi inicialmente apresentado oralmente no dia 16 de outubro de 2017 como Aula Ernesto Veiga de Oliveira, organizada pelo Departamento de Antropologia do ISCTE - Instituto Universitário de Lisboa. 
M.S. Ribeiro 1936), de onde desapareceu El-Rei Dom Sebastião. Estamos perante crenças arquetípicas, mitificações frequentemente instrumentalizadas como suporte ideológico de afirmações identitárias, que sobrevivem pela sua pujança simbólica. Assim sendo, torna-se necessária uma descolonização do conhecimento que nos liberte das amarras mitológicas que, em última instância, nos impedem de tomar os mitos como veículos de conhecimento. Os enredos do fado só são antropologicamente decifráveis se atentarmos na multiplicidade das suas manifestações, nas diferenças deambulatórias que participam nos jogos de identidade, diferenças que se acentuam em trânsitos culturais e cenários de encontro.

$\mathrm{Na}$ tradição do fado, constituída em bases mitológicas, o que verdadeiramente importa são as suas traduções (Robins 1991). Antepondo a tradução à tradição, veremos que os fados do fado resultam de múltiplos trânsitos culturais. A tradução é uma estratégia que nos ajuda a alcançar dispersões conectáveis. Impõe-se então uma decifração dos enredos do fado a partir dos seus cronotopos. Tomo o conceito de cronotopo num sentido próximo do que é proposto por Bakhtin, nos seus estudos literários, ou seja, como uma conexão de relações temporais e espaciais (Bakhtin 1981). Nos cronotopos artístico-literários, espaço e tempo integram-se num todo inteligível, ambos se interpenetrando, o espaço aparecendo como o lado visível do tempo, um tempo que deixa marcas no espaço que o acolhe. Toda a narrativa novelística se afirma como um transcurso no tempo de acontecimentos situados, entre si articuláveis. O mesmo acontece com os cronotopos do fado. Então, se o que está em causa é uma conexão intrínseca de relações temporais e espaciais, exige-se uma metodologia que dê conta da dinâmica processual dessas mesmas relações. Essa metodologia passa por um uso mais intensivo de etnografias multissituadas e pela produção ou recuperação de conceitos que nos possibilitem dar conta das cronotopias dos trânsitos culturais, como os de heterotopia (Foucault 2013 [1984]), rizoma (Deleuze e Guattari 1980), disseminação (Derrida 1972) ou justaposição (Lyotard 1979).

Senti a necessidade desta ancoragem metodológica quando descobri a existência de um fado, em Quissamã, a cerca de $250 \mathrm{~km}$ a norte do Rio de Janeiro, um fado que me disseram vir do tempo dos escravos. Em 2009 viajei até Quissamã para me encontrar com os fadistas e recolher imagens para um documentário. ${ }^{2}$ Quando cheguei a Quissamã e confraternizei com os fadistas,

2 O Fado é Bom Demais..., 2010, Lisboa, Instituto de Ciências Sociais da Universidade de Lisboa, DVD, argumento e direção de José Machado Pais; supervisão de produção, filmagem e edição de Paulo Carrano, disponível em <https://www.youtube.com/watch? $\mathrm{v}=8 \mathrm{aIVLbXSFRQ}>$ (última consulta em fevereiro de 2018). Nesta visita contei com o enorme apoio de um colega e amigo, Paulo Carrano, professor da Universidade Federal Fluminense, e mais três entusiastas estudantes de cinema da mesma universidade, envolvidos nos registos fílmicos: Luciano Dayrell, Sarah Esteves e Eduardo Mendes. Agradecimentos especiais são também devidos aos fadistas António Morin, Guilhermina [continua] 
constatei, na realidade, a existência de diferentes danças de fado: mineira, marreca, tontinha, extravaganza, etc. No entanto, todas elas eram tocadas e dançadas a um ritmo semelhante: com sapateado, batimento de palmas e acompanhamento de viola e pandeiro. Um dos mais respeitados fadistas de Quissamã, o senhor António Morin, comungando da ideia de Gabriel Tarde de que existir é diferir, corroborou: "O fado, cada dia que a gente canta ele... já aprende alguma coisa”. A sua senhora, dona Nadir, sensível também às mutações do fado nas veredas do tempo, relembrou os tamancos que outrora eram usados para batimentos com mãos ou pés, vulgo sapateado. Por seu lado, dona Guilhermina, uma descendente de escravos, preocupava-se em acentuar o lado cristão do fado, insistindo: "o fado é de Deus, ele é bento, ele é sagrado!" Por isso, ao contrário do jongo, argumentou, o fado é dançado em cruz, dois homens e duas mulheres cruzando-se em diagonal. E assim é. Dir-me-ão que o fado de Quissamã nada tem a ver com o fado que hoje se ouve nas casas de fado de Lisboa. Porém, este fado também é muito distinto daquele que existia nas tascas da Lisboa boémia da segunda metade do século XIX (Pais 1985), ao ser dançado com evidentes entrecruzamentos do lundum com o fandango, não faltando o sapateado.

Temos então dois achados instigantes, enigmas a desvendar. Por um lado, por que razão, entre os fadistas de Quissamã, circula a crença de que o fado é de Deus? Por outro lado, como explicar que o fado de Deus seja dançado e sapateado, outrora com tamancos, em jeito afandangado, quando é sabido que o fandango batido, contrapondo-se ao fandango valsado, foi das danças mais perseguidas no Brasil pela sua má reputação, a ponto de hoje apenas sobreviver em algumas regióes do Rio Grande do Sul e do Paraná, e muito residualmente no estado de São Paulo e a norte da Baixada Fluminense? ${ }^{3}$ Para enfrentarmos estes dois enigmas, sugiro tomarmos como eixos analíticos os cronotopos deste fado sapateado. Para Bakhtin (1981), a relevância dos cronotopos pode ser de natureza temática e figurativa. No caso dos fados do fado, a relevância temática ganha evidência na análise de diferentes géneros musicais que entre si se entrecruzam, como o lundum, as modinhas, o fandango, a chamarrita, a cana verde, a chula, etc. A análise temática pode estender-se às letras dos fados, aos aspetos coreográficos das danças - umbigadas, sapateado, volteios ou batimento de palmas -, culminando nas performances dos instrumentos musicais: violas, guitarras, pandeiros, castanholas, sanfonas e tamancos. Para além da relevância temática dos cronotopos do fado, há uma acuidade figurativa em todos esses cronotopos que é dada pelo seu carácter concreto-sensitivo. É a

[continuação] Rodrigues de Azevedo, Maria Nadir e Valdemiro Santana, e ainda ao Complexo Cultural Fazenda da Machadinha, ao Espaço Cultural José Carlos de Barcellos, ao Museu Casa de Quissamã e à Universidade Federal Fluminense.

3 Neste registo não se considera o fandango bailado dos marujos do Norte e Nordeste do Brasil. 
natureza dos cronotopos - conexão de relações temporais e espaciais - que permite que o entrelaçamento de acontecimentos, pessoas, artefactos, tempos e lugares se converta numa realidade libertadora de imaginários e sentimentos. Isso acontece porque o espaço ganha vida, ao assumir-se como o lado visível do tempo, de um tempo social porque tecido de relações sociais. A relevância figurativa dos cronotopos do fado radica na sua capacidade de criar representações sensíveis do fado ou do que à volta dele gira. Dá-nos também a possibilidade de criar cenas, ou melhor, de as podermos imaginar, como uma concreção plástica de encarnação.

Tome-se por exemplo a gíria e os apelidos que circulavam na Lisboa fadista de outrora. A finais do século XIX havia um velho tasqueiro da Mouraria, antigo guarda municipal, João do Grão, expulso da corporação por ter emprestado a farda a uma meretriz num dia de Carnaval. João do Grão faleceu e a taberna passou a ser explorada por outro taberneiro que viria a ganhar a alcunha Fala Baixo. Isto porque, como a sua tasca ficava aberta noite adentro, o taberneiro advertia constantemente os clientes turbulentos para falarem baixo, com receio das rusgas policiais (Santana 2001: 52, 65). Não sabemos a data precisa em que o taberneiro ganhou a alcunha Fala Baixo, mas podemos imaginar um alarido de vozes insolentes, ritmadas com banzas e rodadas de copos de vinho, num tempo em que o fado já era alvo de perseguições. Sabemos, isso sim, que uma das primeiras medidas da ditadura militar que derrubou a I República, em 1926, foi a proibição, no ano seguinte, dos fados noturnos. Mas eles continuaram a ser cantados baixinho, clandestinamente, apesar do temor dos taberneiros, como era o caso do Fala Baixo. A acuidade figurativa destes cronotopos transparece no carácter concreto-sensitivo do tempo notívago das tabernas. Basta atentar no sentimento de revolta que encontramos em algumas letras de fado contra a perseguição policial: "Já não se ouvem lindos temas/ Na rua do fado menor/ A guitarra traz algemas/ O Fado foi p'ró major" - alusão ao major Moura que, no período da ditadura militar, era o terror dos fadistas. As letras de fado, tal como as alcunhas dadas a fadistas, prostitutas e taberneiros, mostram a riqueza temática e figurativa dos cronotopos associados ao fado. Se tivermos presente o livro de Eduardo Galeano As Palavras Andantes, vemos bem como, nas suas andanças, as palavras comportam um signo mediador, cronotópico, que faz com que as significações espaciais e temporais se entrelacem numa busca de sentido compósito, sensitivo. Isto acontece porque a linguagem, por natureza cronotópica, assimila tempos e lugares vividos, por isso é um tesouro de imagens e memórias a que deitamos mão se na mão também tivermos as chaves de interpretação dos significados semióticos da temporalidade (Parmentier 2007; Zerubavel 2016). 


\section{O FADO É DE DEUS}

Em Quissamã, a acuidade figurativa dos cronotopos do fado está bem presente na crença de que o fado é de Deus. De acordo com alguns fadistas, Jesus, ele próprio, terá andado por Quissamã com seu pandeiro e viola. Por isso o fado é dançado em cruz. Esta crença, com roupagens mitológicas, dá a possibilidade de imaginar Cristo numa concreção plástica de encarnação. Qual a razão de ser deste imaginário que faz de Cristo um fadista? Oswaldo Xidieh, em seu livro Narrativas Pias Populares: Estórias de Nosso Senhor Jesus Cristo e Mais São Pedro Andando pelo Mundo, dá-nos conta de mais de meia centena de narrativas coletadas no estado de São Paulo sobre as andanças de Cristo pelo mundo (Xidieh 1993 [1968]). Muitas dessas crenças, produto de um desencontro entre distintas temporalidades históricas, parecem corresponder à necessidade de resistência ou de ajustamento das comunidades rurais às perturbações que tendem a desorganizá-las, como acontece quando surgem ameaças de supressão das festas ou danças populares. A crença no fado de Deus corresponderá, provavelmente, a uma estratégia defensiva em relação ao direito à festa.

Convém lembrar que, nos primórdios da colonização, as danças ameríndias foram esconjuradas com o anátema divino. Festejos indígenas descritos pelos colonizadores como terreiros do diabo ou, ainda, danças participadas por escravos libertos - como o lundum, o jongo ou o fandango sapateado - tinham no Brasil má reputação devido ao seu erotismo. Ao identificarem as danças indígenas como obra do diabo, os jesuítas justificavam a catequização dos nativos também pela domesticação dos corpos, ainda por cima desnudados. Em finais do século XVII, no Pará (Tapajoz), o padre João Felipe Bettendorf (1909 [1699]: 170) descrevia um desses terreiros, mato adentro, com danças, vinhaça, beberronias e feiticeiros com voz rouca de diabo. A excomunhão estendeu-se mais tarde às danças africanas. Sendo Quissamã, nos tempos coloniais, uma região com forte presença de escravos, não estranha que as suas danças tenham também acabado por ser alvo de preconceitos e perseguições, principalmente o jongo, associado a pretos velhos, feiticeiros filiados em irmandades negras, olhadas como antros de rebeldia (Pais 2012). A aproximação do fado a Deus por parte de escravos e descendentes de escravos permitiu a sobrevivência de um tempo festivo. Mesmo no período da Quaresma, os fadistas alegam poder dançar o fado sem receios de pecar, pois, sendo o fado de Deus, a sua dança é bendita. Esta figuração religiosa arrastou um efeito correspondente, a imposição de uma forte contenção da expressividade corporal. Em danças com bênção divina não poderia haver condescendência com esfregações, bate-coxa ou mela-queca. Por isso, na dança do fado de Quissamã não vemos umbigadas, nem outros movimentos libidinosos.

Também as violas populares tinham péssima reputação, principalmente as que Ernesto Veiga de Oliveira (1966) caracterizava pelo seu toque rasgado, 
sonoridade produzida pelo deslizamento das unhas ou dos dedos dos violeiros nas cordas do tampo da viola em ritmos rápidos e sucessivos. As violas populares, descendentes do alaúde árabe e da guitarra mourisca, a cuja família também pertence a guitarra flamenga (Cortés 2012), imperavam nas melodias rústicas e festivas, devido precisamente ao seu toque rasgado. A Igreja olhava com desconfiança as guitarras e violas populares, consideradas uma herança pagã. Em Portugal, começaram a ser perseguidas pelo menos desde meados do século XV. Em 1477, num sínodo realizado em Braga, ameaçava-se de excomunhão todos os que, cumprindo vigília por devoção em igrejas, capelas ou mosteiros, ousassem tanger alaúdes, guitarras, violas e pandeiros, ou cometer outras desonestidades que pudessem provocar a ira de Deus (Morais 2006: 396). Mas já antes, nas Cortes de Lisboa de 1459, D. Afonso V - avisado dos "males que por causa das viollas se sentem por todo o reino", entre os quais o assédio dos tocadores às filhas e criadas dos proprietários de fazendas - determinara que quem fosse achado de noite em cidade, vila ou lugar, com viola ou qualquer outro instrumento de tanger, fosse preso e despojado da viola e armas que trouxesse (M.J.C. Brito 1910 [1459]: 24; Morais 2006: 397). Sob o domínio filipino as perseguições continuaram com os mesmos argumentos. Ordenações promulgadas em 1603, determinavam:

"Por se evitarem os inconvenientes, que se seguem das musicas, que algumas pessoas costumão dar de noite, cantando ou tangendo com alguns instrumentos às portas de outras pessoas; defendemos, que pessoa alguma, de qualquer qualidade e condição que seja, não se ponha só, nem com outros a tanger, nem cantar à porta de outra alguma pessoa, desde que anoitecer, até que o Sol seja saído.

E sendo achados dando as ditas musicas, mandamos que assi os que tangerem e cantarem, como os que a isso assistirem, sejão presos, e stem trinta dias na Cadêa sem remissão, e da Cadêa paguem todos dez cruzados, cada hum a parte, que lhes couber, e percão os instrumentos, que lhes forem tomados, e as armas para o Meirinho, ou Alcaide, que os prender, e para seus homens". ${ }^{4}$

O repúdio em relação às violas era obviamente dirigido aos seus usos populares e profanos. Violas de arco, alaúdes, cítaras, harpas ou saltérios só podiam entrar nas igrejas se as sonoridades mundanas dessem lugar a formas espiritualizadas de expressão musical. Ou seja, a relevância figurativa dos cronotopos das violas transparece no distinto carácter concreto-sensitivo de distintas ambiências

4 Ordenações Filipinas, Livro 5, título LXXXI, "Dos que dão música de noite”, p. 1230 (versão digitalizada da edição de Cândido Mendes de Almeida, Rio de Janeiro, 1870, em < http://www.ci.uc.pt/ihti/ proj/filipinas/ordenacoes.htm > (última consulta em fevereiro de 2018). 
sociais - sagradas umas, profanas outras. Os paladinos da má reputação das violas populares acusavam os violeiros de fazer pactos com o diabo. Dizia-se que frequentavam encruzilhadas e cemitérios, ao bater da meia-noite, para fazerem simpatias com o belzebu. A força da persuasão robusteceu a crença que se instalou no imaginário popular. A superstição, resistindo às mutações do tempo, ainda hoje continua a ser interiorizada por alguns violeiros. Em Rio dos Patos, no Paraná, os fandangueiros colocam dentro da viola um inseto da região (mamangava) para que a viola toque melhor (Andrade e Arantes 2003: 47-48). Outros recorrem a simpatias com cobras: "Temperei minha viola/ Nos olhos da cascavel/ Me embebedei no veneno/ Me empanturrei do seu fel" (J.H. Ribeiro 2006: 135). No entanto, mesmo havendo pactos com o diabo, os violeiros acreditam que Deus acabará por resgatar as suas almas. Porquê? Porque acreditam que as maviosidades da viola são do agrado de Deus (Vilela 2013: 47). Aliás, na arte sacra são abundantes as representações de anjos tocando banzas e alaúdes.

É nestas tessituras do tempo que, entre os fadistas de Quissamã, surge a crença de que o fado é de Deus, independentemente da presença dos pandeiros e violas de toque rasgado. Estamos perante um mito com forte carga simbólica, embora haja um lastro de opacidade em todo o simbolismo. A simbologia consiste na transposição de um sentido concreto para um sentido figurativo. A interpretação da simbologia exige um percurso inverso, a passagem do sentido figurativo ao concreto. Nesse giro interpretativo, a crença dos fadistas de Quissamã no fado de Deus parece corresponder a uma estratégia para assegurar a sobrevivência da festa, numa ambiência social onde as danças indígenas e africanas eram esconjuradas com o anátema divino e as violas de toque rasgado se viam amaldiçoadas. Escravos e descendentes de escravos aderem então à cruz do fado, numa crença reflexiva, crença na crença de outros. Aliás, o cristianismo da casa-grande também era permeável às crendices da senzala, como bem sugeriu Gilberto Freyre (2013 [1933]), em Casa-Grande \& Senzala. Em suma, os cronotopos figurativos dos imaginários sociais encerram crenças que, ao mesmo tempo, libertam pistas para a sua interpretação.

\section{UM FADO SAPATEADO}

Indo agora ao segundo enigma: como explicar que o fado de Quissamã seja dançado e sapateado, outrora com tamancos, em jeito afandangado, quando é sabido que o fandango batido foi das danças mais perseguidas em toda a América do Sul? De facto, para as elites coloniais, os fandangos ofendiam a honestidade e o pudor, para além de aparecerem associados a rixas, bebedeiras e apunhalamentos. No Brasil imperial surgiram penalizações para todos os que organizassem fandangos dando guarida a escravos fugitivos. Especialmente nas regiões de mais forte implantação do fandango, como no estado do Paraná, a 
moralização dos costumes fez surgir legislação municipal repressora. Posturas da Câmara de Curitiba, de 1829, alarmadas com a alegada promiscuidade entre escravos libertos, determinavam a proibição de fandangos e batuques, sob pena de prisão. Os bailes apenas se poderiam realizar "em casas decentes e entre gente morigerada" (Pereira 1996; Balhana e Westphalen 1983).

Dependendo de se tinham ou não batuque, de onde eram realizadas e por quem eram participadas, as danças promoviam uma idealizada fratura moral entre devassidão e decência, mas a clivagem mais fraturante era de natureza social. Uma população considerada perigosa, de gente desordeira - composta de escravos libertos, mulatos e brancos despossuídos - contrapunha-se a gente morigerada, atributo dirigido quer aos trabalhadores humildes e subservientes, quer às classes economicamente possidentes. Ao fim e ao cabo, a música sempre foi usada para expressar identidades e construir barreiras simbólicas entre diferentes grupos sociais. O fandango de má fama só poderia sobreviver caso se libertasse dos batuques. Foi isso que aconteceu em Quissamã, quando os sons dos tambores deram lugar ao batimento dos tamancos. Por outro lado, para que a decência tomasse o lugar da devassidão, o respeito à mulher pressupunha que esta tivesse uma forma de dançar igualmente respeitável, a vergonha impondo--se ao despudor. A moralidade afirmava-se na forma de dançar e também na submissão da mulher ao homem - este impondo o ritmo com firmeza, a mulher acompanhando-o com apatia, indiferença e discretos trejeitos. É esta coreografia que ainda hoje se observa no fado de Quissamã.

Se são evidentes as similitudes entre o fado de Quissamã e o fandango liberto de batuques, importa sublinhar que este fado afandangado não surgiu por acaso. $\mathrm{O}$ fandango que sobreviveu depois da repressão de que foi alvo aparece associado aos mutirões. Mutirão $0^{5}$ é o termo que no Brasil se usa para designar trabalhos recíprocos, coletivos, comunitários (Dias 1953). Em Quissamã, estes trabalhos cooperativos também existiam, findos os quais o fado se dançava pelos escravos das senzalas, principalmente na fazenda da Machadinha. Havia mutirões nas colheitas de cana-de-açúcar e também na construção de casas, feitas de taipa, madeira, palha da vegetação dos charcos e fibras de cipó. O próprio barro para tapar a estrutura de madeira era obtido na fazenda de Machadinha. Acabada a construção das casas, havia lugar para a festa. Em Quissamã, ainda hoje há mutirões que terminam com cachaça, cerveja e muita brincadeira (Guimaraens 1987: 113).

A prática do mutirão, embora com diversas designações, recobre uma realidade historicamente presente em diferentes latitudes geográficas. Nas comunidades andinas, por exemplo, minga (derivado de mink'a, no idioma quechua dos incas) é o termo usado para designar o trabalho coletivo agrícola em

5 A sinonímia usada no Brasil para designar o trabalho mútuo recobre imensos termos, alguns deles afins por corruptela, como mutirão, muxirão, mutirum, puxirin, puxirão, pixurão, putirão e outros. 
benefício de todos. Curiosamente, a palavra encontra-se também no idioma guarani, com o mesmo significado. No Paraguai existe mesmo uma cidade com o nome de Minga Guazú (em guarani: mutirão grande). É discutível a posição dos que situam a origem monogénica destes trabalhos coletivos nas culturas ameríndias, europeias ou africanas. Em 1954, quando Ernesto Veiga de Oliveira apresentou no Brasil uma comunicação sobre "trabalhos coletivos gratuitos e recíprocos em Portugal e no Brasil" (Oliveira 1955), já o antropólogo brasileiro Hélio Galvão (1945) havia criticado a mania da monogénese, defendendo a concomitância das suas origens. Tal não significa que entre mutirões de diferentes latitudes geográficas não possamos encontrar características comuns, como a da reciprocidade social. No entanto, conceitos como os de igualitarismo e homogeneidade social, propostos por Jorge Dias, não são isentos de crítica, como bem defendeu Brian O’Neill (1982). Em alguns mutirões não há sequer reciprocidade. Fazendeiros ricos, a pretexto da festa, convidam trabalhadores rurais, contratam violeiros e acabam por se apropriar de um trabalho gratuito.

Para Ernesto Veiga de Oliveira (1955: 32), é o elemento festivo que confere unidade aos trabalhos coletivos gratuitos, ou seja: o seu "carácter emocional e festivo, intrínseco e subjetivo"; a "euforia do ajuntamento", a "boa refeição em comum, entre graças e histórias", o "erotismo difuso que paira no ar", as "liberdades que ocorrem", as "cantigas, danças e festanças"... É este substrato afetivo e festivo que Ernesto Veiga de Oliveira identifica nos mutirões e afins do Brasil e Portugal. Porém, como esta figuração lúdico-festiva aparece associada ao trabalho, o fandango do mutirão (M.L.S. Brito 2003) acaba por ser aceite pelas classes possidentes. Ainda mais sendo dançado com tamancos. Se tomarmos as coincidências como sinais de reminiscências, há que recordar que os tamancos sempre foram um apetrecho das classes laboriosas, no trabalho ou nos momentos festivos. É o que acontece na região caiçara (termo de origem tupi que significa cerca rústica feita de galhos de árvores), abarcando o sudeste e litoral do Brasil, onde ainda hoje o fandango se dança com tamancos. Os tamancos eram usados no trabalho e na dança, dando-se uma justaposição de diferentes usos. É por esta razão que o fandango de mutirão acaba por ter uma aceitação social generalizada. É festa e trabalho. É um trabalho prazenteiro porque está associado à festa. É uma festa investida por quem dela economicamente beneficia, porque decorre de um trabalho produtivo. Esta ambivalência não invalida que o fandango de mutirão ganhe, cronotopicamente, uma acuidade figurativa, dado o seu carácter concreto-sensitivo como o definiu Bakhtin, ou "emocional e festivo" como sustentava Ernesto Veiga de Oliveira.

No fandango de mutirão há um elemento material de relevância temática que liga a festa ao trabalho: os tamancos. Não por acaso, o fandango batido com tamancos estava principalmente presente em estados produtores de arroz, 
como Mato Grosso, Minas Gerais, Maranhão, Santa Catarina, Rio Grande do Sul, Goiás, Tocantins, São Paulo e Mato Grosso do Sul. As espigas de arroz eram espalhadas pelo chão das casas, em soalho de madeira, com vãos apropriados para que os bagos de arroz pudessem cair sob o porão, depois de pilados com o sapateado (Aguiar e Perrini 2005: 66). O trabalho nos arrozais refletia-se no modo de dançar. No fandango de sapateado, os homens faziam com os tamancos fortes batimentos no chão como se estivessem a esfarelar arroz. Por seu lado, as mulheres rodopiavam as saias como que ajudando a que o farelo se soltasse dos grãos de arroz. Alguns fandangueiros vibravam de tal modo o soalho que acabavam por o rachar ou quebrar. O nome Machado ou Machadinho, pelo menos no Paraná, passou a designar os fandangueiros capazes das mais vibrantes sonoridades com os seus tamancos. Esta vibração sonora não tem equivalência com a expressividade corporal das mulheres. Ao contrário do que acontecia quando o fandango incorporava as umbigadas de influência africana, hoje as mulheres dançam o fandango de uma forma contida. Os próprios fandangueiros continuam a reivindicar a decência do fandango, não tanto como estratégia de sobrevivência de um tempo festivo libertado pelo trabalho, mas, sobretudo, como um património a preservar (M.L.S. Brito 2003; Cortês 1994: 22).

Muitos fadistas de Quissamã, mesmo os descendentes de escravos, como dona Guilhermina, continuam a reproduzir o anátema dirigido às danças de origem africana: "o fado é de Deus, o jongo é do diabo". No entanto, entre os fadistas há receios quanto à sobrevivência do fado de Quissamã. Os batuques voltaram, libertos da opressão a que estavam sujeitos, e o jongo passou a ser dançado mais livremente. As políticas afirmativas surgidas no Brasil na primeira década do presente século, que culminaram na instituição do Estatuto de Igualdade Racial, em 2010, bem como a instituição dos chamados pontos de cultura, no quadro do Programa Cultura Viva, do Ministério da Cultura, permitiram uma revalorização das expressões culturais de afrodescendentes. Isso explica que alguns fadistas, entre os quais dona Guilhermina, embora dancem jongo, tenham receio de que o fado possa vir a desaparecer, tanto mais que os jovens preferem o jongo ao fado. O fadista e violeiro Valdemiro Santana lamentava-se: “[...] trabalhei quase de botar sangue pela boca, passei por muita coisa ruim [...]. E aí fui tocando a vida e estou aqui até hoje. Mas, agora, quando Deus... quando Deus me apanhar, aí pronto, acabou tudo, porque não tem mais ninguém, porque ninguém quer aprender mais [a tocar viola para acompanhar o fado]".

Como chegaram os tamancos ao fado de Quissamã? Por um lado, por uma acuidade figurativa que os associa aos mutirões, ou seja, ao mundo do trabalho. Por outro lado, como resposta ao preconceito contra os tambores do jongo, associados à macumba. Desse modo, não obstante as velhas e recentes ameaças, garantiu-se a sobrevivência das danças afandangadas, como é o caso do fado de 
Quissamã, e o seu carácter emocional e festivo, tão próprio dos mutirões. Numa avaliação cronotópica, vimos também que os tamancos podem ter diferentes usos, associados a ressignificações simbólicas que sobrelevam valores de uso em outros contextos. Não existem festas sem reminiscências do passado, sem memórias avivadas em atos de repetição e comemoração. Contudo, embora repetitiva, a festa cria novos sentidos na repetição, mesmo quando se converte numa tradição reinventada. Nesta medida, a festa surge também como uma estratégia de enfrentamento e de rotura em relação à quotidianidade. Por isso, as ritualizações festivas são armaduras da existência humana, ao possibilitarem roturas nas rotinas de vida.

\section{ENCONTROS DE CAMINHO}

Qualquer pesquisa sobre os trânsitos do fado deixará itinerários na obscuridade. No entanto, é nesses trânsitos que acontece a existência do fado como um devir. Bakhtin vincava a necessidade de valorizarmos os cruzamentos rizomáticos entre cronotopos de encontro e de caminho. Os encontros têm lugar num caminho de interseções. Intersecções de lugares, de tempos, de pessoas, de artefactos. Por isso, o caminho é o lugar de referência e preferência dos encontros. Na história do fado, eles ocorriam nas tabernas, nas hortas dos arrabaldes de Lisboa, nos cortiços do Rio de Janeiro, em ambientes festivos, mesmo quando associados aos mutirões. Aliás, os influxos entre o fandango, o fado e o lundum aparecem entrecruzados com fluxos migracionais. Estes acabam por favorecer os encontros de caminho. Na esteira de Bakhtin podemos dizer que, nos caminhos por onde fluem os trânsitos do fado, se cruzam todos aqueles que geralmente se encontram separados por hierarquias ou diferenças sociais. Não é que desses encontros resulte um esbatimento das diferenças sociais. O que acontece é que elas acabam por confluir no fluir dos trânsitos. Assim, enquanto no Brasil a modinha começou por ser cantada nos salóes aristocráticos e burgueses, vindo depois a ter uma apropriação popular (Lima 2001), em Portugal o lundum, tal como o fado, teve uma trajetória social inversa, chegando aos salões aristocráticos e burgueses depois de imperar nas baiucas dos bairros mais populares da Lisboa boémia.

No Brasil, um dos mais notáveis caminhos de encontro foi Sorocaba, no estado de São Paulo. Principalmente a partir da primeira metade do século XVIII, Sorocaba tinha uma centralidade estratégica no eixo económico entre as regiões Norte, Nordeste e Sul, de onde vinham os muares conduzidos pelos tropeiros. A feira de Sorocaba não era apenas um espaço de negociação de gado, era também um cenário de múltiplas formas prosaicas de trânsito e de performances justapostas. Os negócios misturavam-se com atividades de ócio. Para além dos tropeiros, a Sorocaba chegavam artistas circenses, vendilhões, ladroeiros, tangedores de violas, cantadores, prostitutas, vadios, trapaceiros, 
rufias e ciganos com suas quinquilharias. Viam-se também ciganas lendo a buenadicha. Todos unidos num espaço de convergência e justaposição de enunciações, encenações e interações. Nos pagodes noturnos surgiam poetas repentistas e violeiros com seus ritmos rasgados e o inevitável fandango, não faltando as umbigadas.

Nos trânsitos do fado não podemos menosprezar estes lugares de encontro e o papel que violeiros, tropeiros e cantadores de diferentes paragens tiveram na disseminação de diferentes danças e cantorias. Sem esquecer aqueles cujo contributo tem sido frequentemente silenciado, como é o caso dos ciganos. Recentemente estive em Sorocaba e constatei como a presença dos ciganos continua a ser considerável, embora nem sempre visível. Ao visitar a capela Senhor do Bonfim de João de Camargo, deparei-me com um espaço da capela totalmente consagrado aos ciganos e testemunhei a devoção aos santos ciganos, como Santa Sara Kalí e São Benedito, considerado o cigano de Cristo. Nos cronotopos do fado encontramos lusitanos, ciganos e africanos, do mesmo modo que confluem influências do lundum, do fandango e até do flamengo. Aliás, os defensores das raízes árabes e africanas do fado sempre apontaram a Mouraria e outros bairros populares lisboetas, como Alfama e o Bairro Alto, a que a memória árabe e africana sempre esteve ligada, como núcleos onde o fado se terá estruturado nos seus primórdios. Nas antigas mourarias ouviam-se malagueñas e muitas tabernas de Lisboa do século XIX eram lugares de encontro para as danças do lundum, do fandango e do fado batido.

O fado de Quissamã inscreve-se no universo das chamadas danças batidas, como eram conhecidos alguns fandangos do Brasil - fandangos batidos por implicarem sapateados que se viriam a reproduzir no fado batido, muito em voga nas suspeitas tascas de Lisboa, em finais do século XIX. Também no Rio de Janeiro, na descrição da dança do fado por Manuel António de Almeida, em Memórias de Um Sargento de Milícias (em meados do século XIX), lá encontramos a viola, os estalos de dedos, o sapateado, os volteios e os batimentos de palmas. Nestes encontros de caminho havia uma notável justaposição de danças e cantorias de natureza heterotópica. Mello Moraes Filho dá-nos achegas de prova do entrecruzamento do fado dançado com muitas outras danças presentes em festins roceiros do estado do Rio de Janeiro, em lugares como Boa Esperança e Rio Bonito. Na descrição de um casamento de noivos de famílias "nem muito ricas, nem muito pobres", apareciam violas, rabecas e flautas, enquanto que, no terreiro, os escravos batucavam. Depois vinham as quadrilhas, as valsas, as chulas, as chibas, os fados e os repentes. Quando numa ocasião se dançava a chula, o violeiro aludia ao fado: "Dança o fado, minha gente/ Que uma noite não é nada/ Se eu não for dormir agora/ Dormirei de madrugada" (Moraes Filho 1999 [1901]: 20). Estes ambientes festivos eram propícios à justaposição de géneros heterotópicos que acabavam por se confundir por efeito da beberragem. 


\section{CONCLUINDO}

Com a expressão fados do fado pretendo colocar em evidência os trânsitos rizomáticos que o constituem num enredo de múltiplas disseminações, transformações, variantes e recomposições. Uma problematização teórica dos achados de pesquisa traduz-se numa equação simples: a história do fado de Lisboa não se encerra na história da Lisboa do fado. Com isto não quero dizer que partilhe de uma meta-história que nos impeça de retornar à Lisboa do fado para melhor compreender que realidade é essa que leva o nome de fado. De entre as meta-histórias mais aliciantes, a antropologia estrutural lançou-nos o repto de tomar o tempo como uma realidade fora da qual nada parece existir. Porém, num giro metodológico provindo da linguística saussuriana, a sincronia ganhou ascendência sobre a diacronia. Ora, ao analisar os cronotopos do fado, o que ressalta são entrelaçamentos do tempo com o espaço, sem a consideração dos quais deixaríamos de ser capazes de interpretar os trânsitos culturais. Se nos esquecermos do tempo na penumbra da História ou no roupeiro dos disfarces, como conseguiremos interpretar o presente desvinculado do passado? Esta foi uma questão relevante levantada por Carlo Ginzburg (1991 [1989]), na sua Historia Nocturna. Para os difusionistas, as homologias cavalgariam no dorso do tempo e às mudanças do tempo resistiriam. Isso explicaria, por exemplo, uma relativa ou idealizada estabilidade dos ritos, mitos e tradições. Porém, ao convocar o conceito de cronotopo para a análise dos trânsitos culturais do fado, assumi uma opção metodológica que me levou a trilhar dois caminhos. Por um lado, procurei projetar imagens invertidas do tempo, num trajeto narrativo que foi do presente ao passado para voltar ao presente. Por outro lado, persegui no tempo não apenas rastos de possíveis persistências, mas também de inevitáveis mudanças, já que, como me segredava Gabriel Tarde ao travesseiro, existir é diferir. Na história do fado, tomada como um enredo de trânsitos, os nós desse enredo atam-se e desatam-se nos cronotopos desses trânsitos.

Ao discutirem-se as origens do fado, têm surgido narrativas que reclamam distintas afiliações na base de crenças mistificadoras ou de tradições músico-coreográficas que se tomam como indícios essencialistas dessas afiliações. Frequentemente, desvaloriza-se a complexidade dos trânsitos culturais, a capacidade criadora inerente aos processos que envolvem as trocas culturais. A pesquisa sobre os percursos do fado não pode então ficar aprisionada a indícios essencialistas que se reproduziriam em sua imutabilidade, numa linearidade difusionista. A difusão não impede a reinvenção do que se difunde. Por isso mesmo, as aproximações sincrónicas aos significados do fado exigem questionamentos teóricos de recorte diacrónico. Esta exigência obriga-nos a considerar os trânsitos culturais como processos de comunicação, na linha do que propunha Umberto Eco (1986 [1968]) ao abordar as estruturas ausentes. 
Nos processos de comunicação é importante a tradução. Se, etimologicamente, a tradução vem do latim transferir, transportar entre fronteiras, o fado é certamente uma cultura traduzida, pois, vivendo nas fronteiras da sua existência, em suas vadiagens se inspira e refaz. É essa existência exotópica e cronotópica que faz com que a identidade do fado seja múltipla e se reconstrua na alteridade. Os fados do fado são expressão dessa realidade heterotópica ao transporem os limites do tempo. Por isso vão ganhando novos significados e sentidos, deixando de ser o que eram. Vimos também que nos trânsitos do fado, os seus cronotopos se entrecruzam rizomaticamente em cenários de contacto. O conceito de contacto, que tomo por empréstimo de Mary Pratt (1992), ajuda a dar conta dos aspetos interativos e improvisados dos trânsitos culturais nos encontros coloniais. A questão a debater, teoricamente sensível e que tem escapado às teorias difusionistas, passa então por questionar como os modos de representação de determinadas expressões culturais respondem às relações mutantes que ocorrem em cenários de contacto e, sobretudo, em encontros de caminho. É nestes encontros de caminho que os cenários de contacto se transformam num lugar de condensação de marcas da passagem do tempo. Sem estes marcadores do tempo, dificilmente conseguiremos decifrar os enigmas dos fados do fado. Quer a crença no fado de Deus e as memórias que ela forja na linguagem que a expressa, quer a ardilosa sobrevivência do fado sapateado de Quissamã são exemplos que vos trouxe para refletirmos em questionamentos deste tipo.

\section{BIBLIOGRAFIA}

AgUiAR (MACAXEIRA), Carlos Roberto Zanello de, e Edival PERrini, 2005, Fandango do Paraná: Olhares. Curitiba, HSBC.

ANDRADE, Sandra Maria Leite, e Joceli de Fátima Tomio ARANTES, 2003, "O fandango do Rio dos Patos", em Maria de Lourdes da Silva Brito (org.), Fandango de Mutirão. Curitiba, Editora Gráfica Mileart, 41-50.

BAKHTIN, Mikhail M., 1981, "Forms of time and chronotope in the novel", em Michael Holquist (org.), The Dialogic Imagination. Austin e Londres, University of Texas Press, 84-258.

BAlHANA, Altiva P., e Cecília M. WESTPHAlEN, 1983, Lazeres e Festas de Outrora. Curitiba, Beija-flor.

BARRETO, Mascarenhas, 1923, Fado: Origens Líricas e Motivação Poética. Lisboa, Editorial Aster. BETTENDORF, João Felipe, 1909 [1699], "Chronica da missão dos padres da Companhia de Jesus no Estado do Maranhão", Revista do Instituto Historico e Geographico Brazileiro, LXXII (parte I, capítulo 3: "Breve relação do que obrei pelos Tapajoz, antes do levantamento do Para chegar até lá”). 
BragA, Teófilo, 1885, O Povo Português nos Seus Costumes, Crenças e Tradições, vol. 1. Lisboa, Livraria Ferreira Editora.

BRITO, M. J. da Cunha, 1910 [1459], "Os pergaminhos da Câmara de Ponte de Lima (translado do XXIX capítulo das cortes de Lisboa de 1459, a 12 de Julho do mesmo ano)", O Arqueólogo Português, XV.

BRITO, Maria de Lourdes da Silva (org.), 2003, Fandango de Mutirão. Curitiba, Editora Gráfica Mileart.

CORTÊS, J.C. Paixão, 1994, Danças Tradicionais Rio-Grandenses: Achegas. Passo Fundo, RS, Gráfica e Editora Padre Berthier.

CORTÉS, Norberto Torres, 2012, “El estilo 'rasgueeado' de la guitarra barroca y su influencia en la guitarra flamenga: fuentes escritas y musicales, siglo XVII”, Música Oral del Sur, 9: 288-320.

DELEUZE, Gilles, e Félix GUATTARI, 1980, Mille plateaux: Capitalisme et schizophrénie 2. Paris, Les Editions Minuit.

DERRIDA, Jacques, 1972, La dissémination. Paris, Editons du Seuil.

DIAS, Jorge, 1953, Rio de Onor: Comunitarismo Agro-Pastoril. Porto, Instituto de Alta Cultura, Centro de Estudos de Etnologia Peninsular.

ECO, Umberto, 1986 [1968], La Estructura Ausente: Introducción a la Semiótica. Barcelona, Editorial Lumen.

FOUCAUlT, Michel, 2013 [1984], “De espaços outros”, Estudos Avançados, 27 (79): 113-122.

FREYCINET, M. Louis, 1827, Voyage autour du monde: 1817, 1818, 1819 et 1820, vol. 1.

Paris, Chez Pillet Aîné, Imprimeur-Libraire.

FREYRE, Gilberto, 2013 [1933], Casa-Grande \& Senzala. São Paulo, Global Editora.

GALVÃo, Hélio, 1945, "Mutirão e adjunto”, Boletim Geográfico, 29: 723-731.

GINZBURG, Carlo, 1991 [1989], Historia Nocturna: Un Desciframiento del Aquelarre. Barcelona, Muchnik.

GUIMARAENS, Dinah, 1987, “O maquetista Francisquinho; memória cultural e estética popular; senzalas e casas-grandes em Quissamã; habitações de palha e de barro”, em Maria Emília Prado Marchiori et al., Quissamã. Rio de Janeiro, SPHAM, Fundação Nacional Pró Memória, 107-128.

HOBSBAWM, Eric, 2000 [1983], “Introduction: inventing traditions”, em Eric Hobsbawm

e Terence Ranger (orgs.), The Invention of Tradition. Cambridge, Cambridge University Press, 1-14.

LIMA, Edilson de, 2001, As Modinhas do Brasil. São Paulo. Editora da Universidade de São Paulo.

LYOTARD, Jean-François, 1979, La condition postmoderne: rapport sur le savoir. Paris, Editions de Minuit.

MORAeS FILHO, Mello, 1999 [1901], Festas e Tradições Populares do Brasil. Belo Horizonte e Rio de Janeiro, Editora Itatiaia.

MORAIS, Manuel, 2006, "A viola de mão em Portugal 1 (c. 1450-c. 1789)", Nassarre: Revista Aragonesa de Musicologia, 22 (1): 393-462.

NERY, Rui Vieira, 2004, Para uma História do Fado. Lisboa, Público e Corda Seca.

OLIVEIRA, Ernesto Veiga de, 1955, “Trabalhos colectivos gratuitos e recíprocos em Portugal e no Brasil”, Revista de Antropologia, 3 (1): 21-43.

OLIVEIRA, Ernesto Veiga de, 1966, Instrumentos Musicais Populares Portugueses. Lisboa, Fundação Calouste Gulbenkian. 
O'NEILL, Brian Juan, 1982, “Trabalho cooperativo numa aldeia do Norte de Portugal”, Análise Social, XVIII (70): 7-34.

PAIS, José Machado, 1985, A Prostituição e a Lisboa Boémia do Séc. XIX aos Inícios do Séc. XX. Lisboa, Editorial Querco.

PAIS, José Machado, 2012, "O fado dançado do Brasil: trânsitos culturais", Pensar a Prática, 15 (1): 6-21, disponível em < https://doi.org/10.5216/rpp.v15il.18016> (última consulta em fevereiro de 2018).

PARMENTIER, Richard, 2007, "It's about time: on the semiotics of temporality", Language \& Communication, 27 (2): 272-277.

PEREIRA, Magnus Roberto de Mello, 1996, Semeando Iras Rumo ao Progresso: Ordenamento Jurídico e Económico da Sociedade Paranaense (1829-1889). Curitiba, Editora da Universidade Federal do Paraná.

PRATT, Mary Louise, 1992, Imperial Eyes: Travel Writing and Transculturation. Londres, Routledge.

RIBEIRO, José Hamilton, 2006, Música Caipira: As 270 Maiores Modas de Todos os Tempos. São Paulo, Editora Globo.

RIBEIRO, Mário de Sampayo, 1936, As "Guitarras de Alcácer" e a "Guitarra Portuguesa": Achegas para a História da Música em Portugal, vol. 4. Lisboa, Bertrand.

ROBINS, K., 1991, “Tradition and translation: national culture in its global context”, em J. Corner e S. Harvey (orgs.), Enterprise and Heritage: Crosscurrents of National Culture. Londres, Routledge: $21-44$.

SANTANA, Francisco, 2001 , Dicionário das Alcunhas Alfacinhas. Lisboa, Livros Horizonte.

TARDE, Gabriel, 2007, Monadologia e Sociologia e Outros Ensaios. São Paulo, Cosac Naify (org. Eduardo Viana Vargas).

VILELA, Ivan, 2013, Cantando a Própria História: Música Caipira e Enraizamento. São Paulo, Edusp.

XIDIEH, Oswaldo Elias, 1993 [1968], Narrativas Pias Populares: Estórias de Nosso Senhor Jesus Cristo e Mais São Pedro Andando pelo Mundo. Belo Horizonte, Itatiaia.

ZERUBAVEL, Eviatar, 2016, "The language of time: toward a semiotics of temporality", The Sociological Quarterly, 28 (3): 343-356. 